\title{
Understanding the Pesticide Label for Citrus Grove Workers ${ }^{1}$
}

Brian Boman, Darren Cole, Steve Futch, Ward Gunter, Jack Hebb, Chris Wilson ${ }^{2}$

\section{Read the Label. It's the Law.}

When used properly and according to their labels, pesticides can control, destroy, or repel pests such as weeds, insects, rodents, birds, fungi, bacteria or other organisms that cause loss or damage, or may be harmful to people's health. Pesticides handled in a careless manner can endanger the health of the applicator, other people, animals, plants, or the environment.

Always read the label when you purchase a pesticide, and again before mixing or applying it. The label includes specific information that you should understand including proper handling and use of the pesticide, potential risks the pesticide may pose, and instructions on how to minimize or avoid those risks. Complete understanding of and adherence to the pesticide label will ensure safe and proper use of the chemical.

\section{Before you mix the pesticide, read the label to determine:}

- What personal protective equipment (PPE) needs to be worn during a pesticide application (i.e., gloves, boots, spray suits, and respirators);

- Compatibility of the pesticide with other products or additives;

- Amount of the pesticide to use;

- Methods in which pesticide can be applied; and

- Mixing procedure.

Before you apply the pesticide, read the label to determine:

- Safety measures you should follow;

- Procedures to follow to minimize potential harm to people, animals, plants, or the environment;

- How to apply the pesticide;

1. This document is ABE367, one of a series of the Agricultural and Biological Engineering Department, Florida Cooperative Extension Service, Institute of Food and Agricultural Sciences, University of Florida. Publication date August 2007. Revised March 2009. Please visit the EDIS Web site at http://edis.ifas.ufl.edu for additional publications related to citrus best management practices.

2. Brian Boman, Associate Professor, Darren Cole, Engineering Technician, Steve Futch, Multi-County Citrus Agent, Lake Alfred, Ward Gunter, Engineering Supervisor, P. C. Wilson, Assistant Professor, University of Florida, Indian River Research and Education Center, Ft. Pierce, and J. W. Hebb, Multi-County Citrus Agent, Ft. Pierce. Cooperative Extension Service, Institute of Food and Agricultural Sciences, Gainesville, FL 32611.

The Institute of Food and Agricultural Sciences (IFAS) is an Equal Opportunity Institution authorized to provide research, educational information and other services only to individuals and institutions that function with non-discrimination with respect to race, creed, color, religion, age, disability, sex, sexual orientation, marital status, national origin, political opinions or affiliations. U.S. Department of Agriculture, Cooperative Extension Service, University of Florida, IFAS, Florida A. \& M. University Cooperative Extension Program, and Boards of County Commissioners Cooperating. Larry Arrington, Dean 
- When to apply the pesticide (including the limitations about reentering a treated area and the minimum number of days that must elapse after the application before the fruit can be harvested).

Before you store or dispose of the pesticide or pesticide container, read the label to determine:

-Where and how to store the pesticide.

- How to decontaminate and dispose of the pesticide container.

- Where and how to dispose of surplus pesticides.

\section{Misusing Pesticides}

Every pesticide applicator has the responsibility to read and follow the label information so no harm will result from misuse or mishandling of pesticides. If you are confused about any part of the label, ask your supervisor for help. Many pesticides now list a toll-free number for consumers to call if there are questions.

1. Excessive applications may create a health hazard and cause residues to exceed food safety levels at harvest. This can make the fruit unmarketable.

2. Higher than recommended label application rates may make the worker's environment more dangerous. Each time a pesticide is sprayed, the worker is exposed to the dangers of inhalation or absorption of the toxin.

3. High rate applications may result in adverse effects to the environment. Beneficial insects, earthworms, birds, and other organisms can be harmed or killed in addition to the target pest.

4. Excess pesticides can contaminate the water supply.

5. Continuous or excessive use of certain pesticides may induce resistance in the pests they are designed to control, thus requiring the grower to use combinations of pesticides or other more toxic substances.
6. Some pesticides do not break down easily and can remain in the environment for years.

\section{The Pesticide Label}

The registration and use of pesticides is regulated by the United States Environmental Protection Agency (EPA). Under the amended Federal Insecticide, Fungicide, and Rodenticide Act (Federal Environmental Control Act of 1972 or FIFRA) it is illegal to use any pesticide on a crop unless that crop is listed on the label. It is also illegal to exceed the given rate of application on the label.

\section{What's on a Label?}

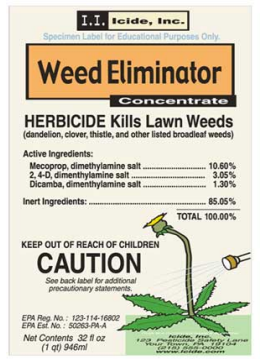

Sample Pesticide Label. Credits: Sample Pesticide Label. From the State of Maine, Pesticide Use: How to Read a Label, www.maine.gov

1. The brand name is used on the front of the label to identify the manufacturer's product.

2. Type of formulation identifies the way the pesticide is mixed for application, usually in one of the following forms:

- emulsifiable concentrate (EC): an oil-based liquid solution mixed with water, then sprayed on the crop;

- flowable or liquid (F or L): a liquid formulation or suspension mixed with water, then sprayed on the crop;

- soluble powder (SP): a powder formed as a suspension in water, then sprayed on the crop;

- granules (G): no mixing required, application is usually dry dispersal;

- solution (S): aqueous liquid ready to mix and apply; or 
- aerosol: ready-to-use spray, air dispersal formulation.

3. The ingredient statement lists the names and quantities of the active and inert ingredients of the product.

4. The active ingredient in a pesticide has a complex chemical name derived from its chemical composition. It may have a common name which is easier to identify. A pesticide may be sold under different brand names, but the same chemical name will appear on all product labels. It is the active ingredient in the product that is responsible for the effectiveness.

5. Net contents indicate the amount of active ingredient per unit weight or volume in the container. The law also requires the maker or distributor of a product to print the name and address of said company on the label, along with an establishment number indicating which factory formulated the chemical.

6. An EPA registration number indicates that the product has been registered with the United States Environmental Protection Agency for label usage.

7. The signal word and symbol on the label indicate how toxic a product is. Signal words to look for are Danger (Skull and Cross Bones), or Highly toxic, Warning (Moderately toxic), and Caution (Slightly toxic).

8. Emergency first aid measures appear if the product is harmful when swallowed or inhaled, or can damage eyes or skin. And also indicate exposure conditions that require immediate medical responses.

9. An environmental hazards section explains the chemical's effect, if any, on the environment. Some examples include the following statements:

- "This product is highly toxic to bees exposed to direct treatment or residues on crops."

- "Do not contaminate water when cleaning equipment or when disposing of wastes."
- "Do not apply where runoff is likely to occur."

10. The directions for use section includes a listing of the pests the product controls, and the crops, animals, or other items on which the product can legally be used. Also included are directions on:

- How the product should be applied.

- How much product to use.

- Where and when the product should be applied.

This is often the most difficult part of the label to follow and, therefore, needs careful consideration. If supplemental information is needed for a crop protection product, consult the material safety data sheet (MSDS). The three items usually found there are the reentry interval, misuse statement, and storage and disposal directions.

- Reentry Interval is the amount of time that must pass from the time of application until it is safe to reenter the area without personal protective equipment or PPEs. This is the time required for the residue to diminish to worker safe levels.

- Misuse statement is a reminder that it is a violation of Federal law to use a product in a manner inconsistent with its labeling.

- Storage and disposal directions, as directed by the EPA and local governments, must be followed for environmental and human safety.

\section{The Proper Gear}

Before working with pesticides always read the label especially the precautionary statements. Complete a checklist review to assure you have the right kind of protective clothing. Careful attention to the correct Personal Protective Equipment (PPE) apparel can minimize pesticide exposure. Additional detailed information on PPE can be found in a document titled "Personal Protective Equipment for the Citrus Grove Worker" (http://edis.ifas.ufl.edu/AE244). 


\section{Pesticide Label Quiz}

\section{$\underline{\text { True or False }}$}

1. Applying pesticides at a rate higher

than listed on the label is against the law.

2. Information concerning PPE

requirements to mix, load or apply a pesticide is found on the label.

3. environmental problems.

4. Repeated use of a certain pesticide may cause pests to become resistant to that pesticide.

5. It is illegal to use a pesticide on a crop unless that crop is listed on the label.

\section{Multiple Choice}

6. A products identifies the manner in which that pesticide is mixed for application. (e.g. Liquid)

a) Formulation

b) Ingredient Statement

c) Net Contents

7. The lists the names and amounts of the active ingredients and the amount of inert ingredients.
a) Formulation
b) Ingredient Statement
c) Net Contents

8. The indicates the amount of the product in the container.
a) Formulation
b) Ingredient Statement
c) Net Contents

9. The in a pesticide has a complex chemical name derived from its chemical composition.
a) Brand Name
b) Active Ingredient
c) Code Name

10. This signal word is sometimes seen with a skull and crossbones and is the most toxic.
a) Caution
b) Warning
c) Danger

Quiz Answers.

\begin{tabular}{|c|c|c|c|}
\hline $\begin{array}{c}\text { Question } \\
\text { Number }\end{array}$ & $\begin{array}{l}\text { Correct } \\
\text { Answer }\end{array}$ & $\begin{array}{c}\text { Question } \\
\text { Number }\end{array}$ & $\begin{array}{l}\text { Correct } \\
\text { Answer }\end{array}$ \\
\hline 1 & True & 6 & A \\
\hline 2 & True & 7 & $B$ \\
\hline 3 & True & 8 & $C$ \\
\hline 4 & True & 9 & $B$ \\
\hline 5 & True & 10 & $C$ \\
\hline
\end{tabular}

\section{References}

Clemson University, Pesticide Information Program, http://entweb.clemson.edu/pesticid/

Environmental Protection Agency, Pesticides: Regulating Pesticides, http://www.epa.gov/pesticides/pestlabels/

Michigan State University Extension, Reading a Pesticide Label, http://web1.msue.msu.edu/imp/mod02/01500584.html

North Dakota State University, Pesticides: Learning about Labels, http://www.ag.ndsu.edu/pubs/plantsci/pests/ a1098w.htm

Virginia Cooperative Extension, Understanding Pesticide Labels, http://www.ext.vt.edu/pubs/envirohort/426-707/426707.html 


\section{Additional Reading}

The following publications that provide information for citrus grove workers are available through EDIS, the UF/IFAS on-line Electronic Document Information Source.

\section{English}

(Forthcoming) First Aid, Heat Stress, and Safety for the Citrus Grove Worker, http://edis.ifas.ufl.edu/AE242

(Forthcoming) Personal Protection Equipment for the Citrus Grove Worker, http://edis.ifas.ufl.edu/AE244

(Forthcoming) Equipment Safety for Citrus Grove Workers, http://edis.ifas.ufl.edu/AE245

(Forthcoming) Herbicide Application Best Management Practices for the Citrus Grove Worker, http://edis.ifas.ufl.edu/AE246

(Forthcoming) Pesticide Application Best Management Practices for the Citrus Grove Worker, http://edis.ifas.ufl.edu/AE247

(Forthcoming) Fertilizer Application Best Management Practices for the Citrus Grove Worker, http://edis.ifas.ufl.edu/AE248

(Forthcoming) Aquatic Vegetation Management Best Management Practices for the Citrus Grove Worker, http://edis.ifas.ufl.edu/AE249

(Forthcoming) Drainage Management Best Management Practices for the Citrus Grove Worker, http://edis.ifas.ufl.edu/AE250

(Forthcoming) Irrigation Management Best Management Practices for the Citrus Grove Worker, http://edis.ifas.ufl.edu/AE251

(Forthcoming) Riser Board Water Control Structures Best Management Practices for the Citrus Grove Worker, http://edis.ifas.ufl.edu/AE252

(Forthcoming) Best Management Practices for Agricultural Maintenance Facilities, http://edis.ifas.ufl.edu/AE253

\section{Spanish}

(Forthcoming) Primeros Auxilios, Insolación y Seguridad para los Trabajadores de Cítrico, http://edis.ifas.ufl.edu/AE270

(Forthcoming) Entendiendo la Etiqueta del Pesticida para los Trabajadores de Cítrico, http://edis.ifas.ufl.edu/AE271

(Forthcoming) Equipo de Protección Personal para los trabajadores de Cítrico, http://edis.ifas.ufl.edu/AE272

(Forthcoming) Seguridad con el Equipo para los Trabajadores de Cítrico, http://edis.ifas.ufl.edu/AE273

(Forthcoming) Mejores Prácticas de Manejo en Aplicaciones de Herbicida para los Trabajadores de Cítrico, http://edis.ifas.ufl.edu/AE274

(Forthcoming) Mejores Prácticas de Manejo en Aplicaciones de Pesticida para los Trabajadores de Cítrico, http://edis.ifas.ufl.edu/AE281

(Forthcoming) Mejores Prácticas de Manejo en Aplicaciones de Fertilizante para los Trabajadores de Cítrico, http://edis.ifas.ufl.edu/AE275

(Forthcoming) Mejores Prácticas de Manejo en Aplicaciones de Malezas Acuáticas para los Trabajadores de Cítrico, http://edis.ifas.ufl.edu/AE276

(Forthcoming) Mejores Prácticas de Manejo con Drenaje para los Trabajadores de Cítrico, http://edis.ifas.ufl.edu/AE277

(Forthcoming) Mejores Prácticas de Manejo con Irrigación para los Trabajadores de Cítrico, http://edis.ifas.ufl.edu/AE278

(Forthcoming) Mejores Prácticas de Manejo con compuertas de retención de agua para los Trabajadores de Cítrico, http://edis.ifas.ufl.edu/AE279

(Forthcoming) Mejores Prácticas de Manejo para el Mantenimiento en Facilidades Agrícolas, http://edis.ifas.ufl.edu/AE280 